\title{
A Case of Spontaneous Extracranial Epidural Emphysema
}

\author{
Sankalp Gokhale ${ }^{a}$ Sanjay Gokhale ${ }^{b}$ \\ ${ }^{a}$ Department of Neurology, Duke University School of Medicine, Durham, N.C., USA; ${ }^{\text {b }}$ Department of Pediatrics, \\ Rajhans Hospital, Saphale, India
}

\section{Key Words}

Epidural emphysema · Spontaneous extracranial epidural emphysema $\cdot$ Subcutaneous emphysema

\begin{abstract}
Objective: To report a rare case of spontaneous extracranial epidural emphysema. Clinical Presentation and Intervention: An 18-year-old woman with a recent diagnosis of squamous cell carcinoma of the esophagus presented with acute onset of cough, dyspnea and subcutaneous emphysema. An esophageal endoscopy revealed an ulcerative lesion in the upper third of the esophagus that was diagnosed as squamous cell carcinoma. A computed tomographic scan of the chest showed spinal epidural emphysema in addition to pneumomediastinum and pneumoperitoneum. A few days later, the patient died of aspiration pneumonia and persistent epidural emphysema. Conclusion: The spontaneous extracranial epidural emphysema in our case resulted from a bout of cough with tracking of air from the pneumomediastinum through the emaciated tissue planes into the epidural space.
\end{abstract}

(c) 2013 S. Karger AG, Basel

\section{Introduction}

The presence of air in the epidural space is known as epidural emphysema. Usually, epidural emphysema is seen in the cranial space, known as cranial epidural em- physema. This situation is quite common in post-neurosurgical patients. However, the presence of air in the extracranial epidural space is not commonly encountered. When encountered, it is usually seen in patients with spine surgeries, spinal tap or trauma [1]. The presence of spontaneous extracranial emphysema is a rare radiological finding, rarely reported in case reports [2]. We hereby present a rare occurrence of spontaneous extracranial emphysema associated with esophageal carcinoma in a patient with a violent bout of cough.

\section{Case Report}

An 18-year-old woman was brought to the Emergency Department of Rajhans Hospital, Saphale, India, for evaluation of a sudden bout of worsening cough. She started having a bad bout of cough a few hours before presentation and developed rapidly progressive diffuse swelling of the chest wall. She complained of progressive shortness of breath and vague chest pain shortly after the bout of cough. Her past medical history was significant for the diagnosis of squamous cell carcinoma of the upper esophagus a few days prior to when she had presented to the outpatient clinic with progressive dysphagia, weight loss and chronic fatigue. An esophageal endoscopy revealed an ulcerative lesion in the upper one third of the esophagus and the biopsy was diagnostic of squamous cell carcinoma. She was scheduled to see an oncologist for the carcinoma in few days. She did not have any history of pulmonary disease. Family history was unremarkable. She was not on any outpatient medications and was not allergic to any known medication.

\begin{tabular}{ll}
\hline KARGER & $\begin{array}{l}\text { ○ 2013 S. Karger AG, Basel } \\
1011-7571 / 13 / 0232-0177 \$ 38.00 / 0 \quad \text { Karger }\end{array}$ \\
E-Mail karger@karger.com & $\begin{array}{l}\text { This is an Open Access article licensed under the terms of the } \\
\text { Creative Commons Attribution-NonCommercial 3.0 Un- } \\
\text { ported license (CC BY-NC) (www.karger.com/OA-license), } \\
\text { applicable to the online version of the article only. Distribu- } \\
\text { tion permitted for non-commercial purposes only. }\end{array}$
\end{tabular}

Dr. Sankalp Gokhale

Department of Neurology

Duke University Hospital

Durham, NC 27710 (USA)

E-Mail sankalpsgokhale@gmail.com 
On examination she was emaciated and febrile with temperature of $39.5^{\circ} \mathrm{C}$, tachycardic with a heart rate of 110 beats $/ \mathrm{min}$, and tachypneic, breathing up to 25 times a minute with oxygen saturation of $94 \%$. Her blood pressure was $90 / 60 \mathrm{~mm} \mathrm{Hg}$. Examination of the chest wall revealed diffuse crepitus, thus there was clinical evidence of subcutaneous emphysema. The remainder of the physical examination did not show any obvious abnormalities.

She underwent an urgent chest X-ray, which demonstrated evidence of air in the subcutaneous space over the chest wall, thus confirming the diagnosis of subcutaneous emphysema. She underwent an emergency computed tomogram scan of the chest which showed subcutaneous emphysema, evidence of air in the mediastinum (pneumomediastinum), evidence of air in the peritoneal cavity (pneumoperitoneum) and, interestingly, a rare finding of evidence of air in the epidural space in the thoracic spine (epidural emphysema) (fig. 1).

She underwent emergency evaluation by a surgical team to evaluate the source of the potential air leak. Due to the locally advanced nature of esophageal carcinoma, she was thought to be a high-risk surgical candidate. The potential morbidities and possible mortality were discussed with the family members. She was transferred to the oncology unit and underwent palliative radiation and pain control. She developed aspiration pneumonia leading to sepsis and succumbed to her illness a few days after inpatient admission. She had persistent epidural emphysema until death.

\section{Discussion}

This was a case of a rare occurrence of spontaneous extracranial epidural emphysema associated with esophageal cancer. Generally, extracranial epidural emphysema is localization of air within the extracranial epidural space $[1,2]$, which is distinct from cranial epidural emphysema that can be seen in penetrating head injuries or infections with gas-forming organisms such as clostridia. It is important to realize that the epidural space surrounding the brain and the epidural space surrounding the spinal cord are two distinct spaces that do not communicate with each other. The spaces are separated distinctly by a tight dural layer at the level of the foramen magnum. Therefore, air does not travel from the cranial epidural space to the spinal epidural space. For these anatomical reasons, extracranial epidural emphysema is rare.

Usually, epidural emphysema is limited to a few vertebral spaces. The most common described reasons are invasive spinal procedures such as open spine surgery or spinal tap, infections with gas-forming organisms, rupture of the intervertebral disk, or sometimes air emboli through communication with the pelvic venous plexus [3-5]; less commonly, it is secondary to mediastinal air that tracks into the epidural space. In our case, there was

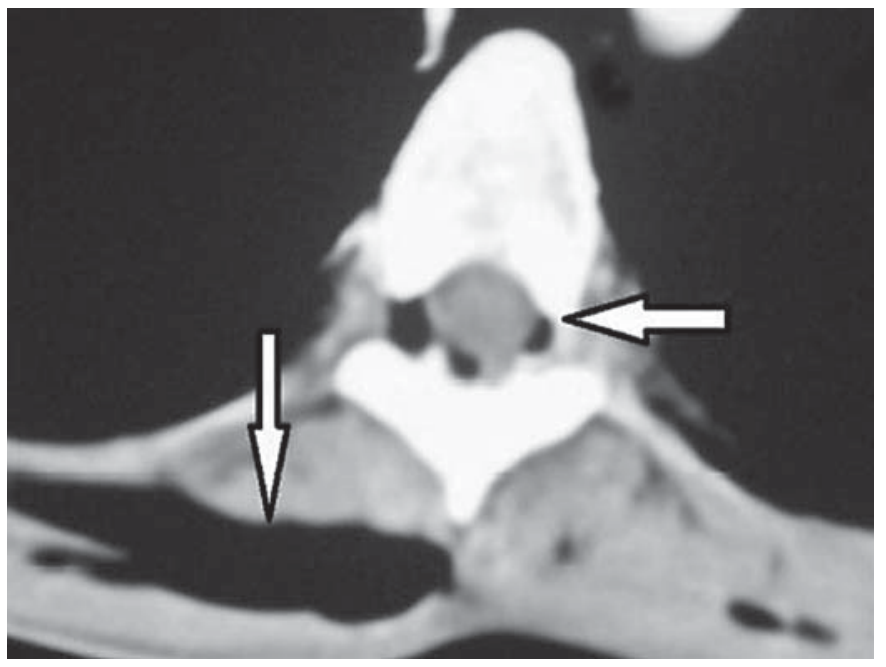

Fig. 1. Computed tomogram scan of the chest, with focused image of the vertebral body showing epidural emphysema (horizontal arrow), and subcutaneous emphysema (vertical arrow).

probably weakness of the mediastinal connective tissue due to body wasting and malignancy. The sudden bout of cough, most likely due to aspiration, likely caused a rise in intrathoracic pressure. This rise in intrathoracic pressure together with connective tissue that was weak as a result of malignancy then allowed the air to extend from the airways to the mediastinal cavity. The air leak then likely travelled from the mediastinum into the epidural space via the cervical fascial planes and intervertebral foramen [6].

\section{Conclusion}

The extracranial epidural emphysema of this case resulted from a bout of cough with tracking of air from pneumomediastinum through emaciated tissue planes into the epidural space. This is a rare radiological sign and when seen, should alert the radiologist and the clinician to a potentially serious underlying medical condition, such as the malignancy in our case.

\section{Acknowledgements}

We would like to thank Dr. Sanjay Mehta and Dr. Milind Ranadive, Departments of Radiology and Medical Oncology, respectively, Rajhans Hospital, Saphale, for their kind assistance. 


\section{References}

1 Cloran F, Bui-Mansfield LT: Extracranial epidural emphysema: pathway, aetiology, diagnosis and management. Br J Radiol 2011;84: 570-575.

$>2$ Hanada T, Ishikuro A, Hasegawa Y, et al: Two cases of spontaneous epidural emphysema during asthmatic attack. Respir Investig 2012; 50:62-65.
3 Mortensen WW, Thorne RP, Donaldson WF III: Symptomatic gas-containing disc herniation: report of four cases. Spine 1993;18: 2533-2536.

4 Goh BK, Allen WYY: Traumatic pneumorrhachis. J Trauma 2005;58:875-879.
5 Charles RW, Mody GM, Govender S: Pyogenic infection of the lumbar spine due to gasforming organisms: a case report. Spine 1989; 14:127-129.

6 Kono T, Kuwashima S, Fujioka M, et al: Epidural air associated with spontaneous pneumomediastinum in children: uncommon complication? Pediatr Int 2007;49:923-927. 